\title{
Views and Experiences of Third-year, Early Childhood Education, University Students about Science Education in Junior and Senior High School
}

\author{
Liana Stylianou $^{1}$, Katerina Plakitsi ${ }^{2, *} \&$ Georgia Papantoniou ${ }^{2}$ \\ ${ }^{1}$ Head of the Environmental Education, Centre of Naousa, Greece \\ ${ }^{2}$ Department of Early Childhood Education, School of Education, University of Ioannina, Ioannina, Greece \\ *Correspondence: Department of Early Childhood Education, School of Education, University of Ioannina, Ioannina, \\ Greece. E-mail: kplakits@gmail.com
}

Received: May 16, 2015

Accepted: October 20, 2015 Online Published: February 9, 2016

doi:10.5430/wje.v6n1p25

URL: http://dx.doi.org/10.5430/wje.v6n1p25

\begin{abstract}
Research on Junior and Senior high school students' attitude toward SE (Science Education) courses focuses on students' attitudes, views, interests and perceptions stemming from their school experiences related to the courses. This study examines the way third-year students of the Early Childhood Education Department in Ioannina have viewed and experienced SE teaching in Junior and Senior high school. The purpose of this paper is to investigate how the members of the above target group, perceive in present time their future role as SE teachers and how their past role as students who have experienced Science teaching in Secondary Education has influenced their attitude toward Science. Factors that shape a positive attitude toward SE, so that students as future teachers and adults who care about being scientifically literate occupy themselves with it, are anxiety about SE courses, self-esteem related to the comprehensibility of the courses, their perception of how significant SE is, learning motivation, delight in dealing with $\mathrm{SE}$, classroom environment, fear of failure or success in the course, but most of all, the way (teaching practices and strategies) SE was taught by Science teachers in Secondary Education.
\end{abstract}

Keywords: teaching SE (Science Education), learning motivation, innovative educational practices, teacher training, approaches and perspectives, teaching methodology

\section{Introduction}

Students' attitudes toward Science and SE (Science Education) teaching are issues of concern to SE research community, since a decrease in the number of students choosing Science in Higher Education results in a limited number of qualified people in both industry and education. The significance and interest in researching young people's perceptions, interests, attitudes to Science are also underlined by the fact that the last three programs - the EU framework - have used a thematic entitled "Science and Society" (Framework Programme 6; Framework Programme 7; Horizon 2020) as a central pillar to improve the level of scientific literacy and raise young people who will pursue a career in Science. Young people's interests, perceptions, motivations, values and actions, related to Science, are regarded as basic research data on scientific literacy (OECD, 2006; Weinburgh \& Englehard, 1994).

The case study is that the more we know about students' interests, likes and dislikes, beliefs, attitudes, the more likely we are (Jenkins, 2006) to develop attractive SE Analytical programs for students. Consequently, problems such as the reduction of students' interest in Science and SE courses, low self-esteem concerning their comprehensibility of Science, negative attitudes (Britner \& Pajares, 2006; Britner, 2008; Gough, 2002; Sjøberg, 2002), low levels of scientific literacy, stereotypical perceptions of Science and Scientists (Christidou, 2011) will be eliminated.

Research on students' attitudes to SE teaching ascertained a reduction in students' interest in engaging themselves with SE professionally. Debate focused both on citizens' widespread ignorance of science (Miller, Pardo, \& Niwa, 1997) and yet the acknowledgment of the importance, economic utility and cultural significance of scientific knowledge. Therefore, promoting a favorable attitude towards science and Science teaching are of great concern. However, the concept of attitude towards science is often unclear and incomprehensible. Education is not a linear, 
predictable system that allows the factors that define learning to precisely adjust. On the contrary, it is a complex, open, interactive system with the members of a school community interacting with and influencing each other. Factors that contribute to the configuration of students' attitudes toward SE are their teachers' perceptions of it, their stress about it, their perception of its significance, their self-esteem related to it, their learning - engagement motivation, delight in engaging themselves in it, their classmates and friends' attitude to it, their parents' attitude to it, their classroom environment, their fear of failure to it or success in it (Oliver \& Simpson 1988; Osborne, Simon, \& Collins 2003; Woolnough, 1994).

Students' knowledge about Science is often confusing as there is no comprehensive assessment of the nature of Science and the work undertaken by scientists and technologists (Hill \& Wheeler, 1991). Knowledge is superficial, vague and it sometimes reflects total ignorance (Scherz \& Oren, 2006). Their perceptions of Science and scientists are limited, inaccurate, stereotypical and controversial (Finson, 2002; Rubin, Bar, \& Cohen, 2003). A contradiction between students' attitude toward SE in general and SE courses taught at school shows the differentiation between students' perception of Science formed by modern technological achievements they come round in their everyday life and their perception of Science as taught at school presenting the most important aspects of science as a series of milestones that are seen through the most important discoveries of the last century. Students' attitudes toward SE courses vary according to scientific fields (Havard 1996; Osborne \& Collins 2000). Biology is relevant to students' interests and daily lives, physics and chemistry are not. For students, anything connected to memorization is invidious. Not only do students get difficulty in memorizing, but also they do not acknowledge its importance, either for the present, or future as memorization is not interesting and relevant to their everyday life. Furthermore, technological applications presented in books are uninteresting because they are not related to their everyday life which is the key to interest.

Classroom environment is considered to be a determining factor in the configuration of attitudes to SE courses. Myers and Fouts (1992) found out that a key factor in shaping positive attitudes to SE is their Science teachers' qualitative teaching. Lack in teachers' pedagogical training is deterrent to the majority of students, showing that although being cognizant of their object, teachers fail in their primary duty to shape various learning opportunities and make their students understand the lesson.

Students regard scientific knowledge as an important element of their education, acknowledging its significance so as to explain their daily routine. However, they focus on the functional significance of Science (ex. professional career) due to their genuine interest in it (Osborne \& Collins, 2001). Students get interested in Science when they see it as a means of promoting practical skills, a proposal for a socioeconomic enterprise, a vehicle to emotional experience, a challenge and mental endeavor, a vehicle to a professional career (Häussler \& Hoffmann, 2000).

Evidence shows that children enter Secondary education while being extremely positive and interested in Science and SE teaching. Experiences in Secondary education lead to a very rapid reduction on interest especially for girls (Breakwell \& Beardsell 1992; Kahle \& Lake 1983). From the age of 14 and up, biology is students' favorite subject while Chemistry and Physics are the least popular ones (Osborne, Simon, \& Collins, 2003).

Oliver and Simpson (1988) argue that there is a strong relation among students' attitude to SE, their motivation to reach their goals and their self-perception of their own ability to comprehend SE and be "good" students. Pleasant and positive childhood experiences influence their interest in Science. Feelings of pleasure and interest combined with success in Science courses are likely to lead to a longitudinal positive relation with SE.

Research on the attitude to SE and SE courses focuses on attitudes, perceptions, and views, which are the result of students' experiences stemming from SE teaching in school. The present study has examined the way third-year students of the Early Childhood Education Department of the University of Ioannina have viewed and experienced SE teaching in Junior and Senior high school. Three years after graduating from Secondary Education, they have formed an opinion about SE courses taught in Junior and Senior high school. Students have been emotionally distanced from positive or negative situations they had experienced throughout their apprenticeship. The purpose of this research is to indicate the way those third-year university students perceive their future role as Science teachers and whether their experiences in SE courses, while they were students in Secondary Education, have affected their attitude toward SE. Finally, the present study aims to indicate the possibility for those experiences to have determined students' attitude to Science and them as adult citizens who may want to be scientifically literate.

\section{Method}

Research was based on a qualitative methodological design because, on the one hand, it was consistent with a 
general epistemological proposal for a research tool chosen in cases about teachers' perceptions. On the other hand, it facilitated and covered its basic objectives (Eisner, 1991). The following methodological model was determined by a general debate between positivist research and traditional research on participants' perceptions. Therefore, the researcher used a semi-structured interview in order to get deep information about the fact being studied. Thus, more data could be elaborated or interview questions be further probed. Questions were open and every participant replied according to his/her experiences while being a student. It was thought that the specific model highlighted students' perceptions of SE and SE teaching through obtaining information and data in depth without requiring researchers' perceptions or a general theory. Interview data was a tape-recorded tool supported by field notes taken during and after each interview.

A research study has been conducted in the Early Childhood Education Department of the University of Ioannina and lasted from November 2013 to January 2014. It involved 187 students in the fifth semester. It was conducted during workshops on teaching preschoolers SE concepts (ex. sound) and it was in the form of open questions. Before each workshop, participants were asked to answer questions regarding their perception of Science courses as they had experienced it when they were students in Secondary Education.

The questions asked were:

1) What is your opinion about SE courses and the way you were taught as a student of Junior and Senior high school? Why?

2) How would you like them to be taught?

3) What do you consider to be the most important thing you have learned / remembered about these courses?

The questions were open and each and every participant replied based on his/her experiences while being a student of Junior and Senior high school.

\section{Results}

Students who have a positive view about SE courses in Junior and Senior high school were found to think that interest comes mainly from the way of teaching and emphasize on experimentation while the topic follows. "Inclination" is a concept that plays an important role in the choice of SE courses. A "good" teacher is one who can arouse students' interest applying appropriate and child-centered teaching practices, overcoming book limits, developing an equal dialogue, giving explanations and clarifications to questions that arise. SE is objective, rationalistic, and promotes research thinking and rationalism. SE is valuable in adult life as it offers scientific knowledge about Physiology and the Environment, resolves routine issues and questions about natural phenomena. SE raises awareness and sensitizes to the Environment which is integral to the study of SE.

Students who have a negative view about SE courses were found to describe their memories and feelings from their experience in Junior and Senior high school, unlike the first group whose members describe the learning process. The former have a positive perception of the role of SE in society but a negative one of SE courses. Lack of interest and motivation at school prevented them from becoming scientifically literate future citizens. Thus, as adults, they are unlikely to deal with issues related to SE. SE courses provide no learning motivation since they are not connected to reality and students' interests. On the contrary, they are invidious, uninteresting. They are like chores which transform into students' hatred. That's because, students are forced to memorize incomprehensible chapters in order to have a dignified performance in class. Memorizing texts and mathematical formulas is useless since it is not utilized in everyday life and it is not appealing as well (Papantoniou, Moraitou, Kaldrimidou, Plakitsi, Filippidou, \& Katsadima, 2012).

Students' attitudes vary depending on which SE course is being taught. Biology is regarded positively as the topics it negotiates and the way it is taught arouses students' interest. Chemistry arouses moderate interest and Physics is a hateful course (Ormerod, 1971; Whitfield, 1980). Students connect mathematics with Physics which focuses on students' doing exercises and learning formulas. The problem with students' interest in SE depends on the quality and type of teaching at school (Krapp \& Prenzel, 2011). As students move from Elementary to Secondary Education, they rapidly lose interest in SE (Christidou, 2011). The way of teaching in Elementary School sustains students' steady interest and enthusiasm in the course. In Junior high school though, the way of teaching differentiates and there is a gradual reduction of interest due to the monotony and emphasis on theory and exercises. What is more, in Senior high school, students who do not choose SE courses lose thorough contact with it and lead themselves to complete denial and rejection. 
SE, taught at school, aims at preparing students for their admission to Higher Education. This is deterrent to students' comprehensibility of SE. Some students may not wish expertise which is offered to them as abrupt concepts, let alone the fact that books and teachers are the sole sources of information. Students' participation is limited during experimentation. Not only are experiments conducted under teachers' instructions, but also they are merely demonstrated and limited to answers (written or spoken) given to the teachers' questions. The monotony of the course due to the way it is taught (through a monologue without visual aids, experiments, practical exercises, but only listing formulas, definitions and solving exercises). Current students insist on the need to carry out experiments at school. They regard them as the panacea for their comprehensibility of SE. Awareness of new teaching approaches in SE, supported by contemporary postmodern visual education in SE, seems to be incomplete. Although students considered SE to be of high importance and to help people understand and utilize various concepts related to natural and structural environment in everyday life. Students experience SE courses as a necessary evil process so as to enter a university of their choice. SE courses are valuable only for students who choose Science Direction for their admission to a university. Unfortunately, the significance of knowledge provided through SE courses but also the significance of general education is not well-perceived. International literature often presents researches which describe a repulsion between students and SE courses (Breakwell \& Beardsell, 1992; Britner, 2008; Britner \& Pajares, 2006; Gough, 2002; Oliver \& Simpson, 1988; Osborne, Simon, \& Collins, 2003; Sjøberg, 2002; Woolnough, 1994).

Students' negative attitude toward SE was due to their difficulty in comprehending the course because of the curriculum, the suggested way of teaching and teachers' perceptions of teaching. The uninteresting presentation of incomprehensible formulas and definitions with no utility significance neither created learning motivation, nor demonstrated the significance of the course in real life. A teacher-centered teaching, that does not include students' meaningful participation, does not enhance students' interest. Students said that the course would, potentially, be interesting, if teachers had applied a different way of teaching and showed genuine interest in them. So, as for students, successful teaching includes enthusiastic teachers with pedagogical competence, content knowledge and technical knowledge. Enthusiastic teachers connect the course with everyday situations, implement actions and activities outside the school, are amiable, dedicate time to students inside and outside the classroom, talk on equal terms with students about issues of Science, career orientation and other problems and topics of interest to students.

Students' self-esteem is low; they consider themselves not to be able to comprehend SE courses. Negative classroom environment is fed with students' stress during examination process, their negative attitude, the ambiguity of concepts. In order for students to stand before their teachers with dignity and take a coveted degree, they are forced to memorize the lesson, mechanically memorize information they poorly understand or do not understand at all. Passive memorization aims to students' holding information in mind and then "depositing" it to their teacher. Their teacher, in turn, will rush to reward the result with a privileged grade without actually exploiting students' cognitive ability. The continuous emphasis on classroom environment during SE courses, especially throughout Senior high school, shows the importance of the environment for a successful learning process, but also the problem that unfortunately becomes obvious. Classroom environment relates to the dynamics developed in a classroom, how children feel and experience classroom environment based on their common understanding of an environment on educational, psychological, social, material dimensions (Sink \& Spencer, 2005). Classroom environment is improved when a teacher provides intrinsic motivation to engage students in Science and not only SE courses.

Factors that do not help students comprehend SE courses vary among teachers' pedagogical insufficiency, inappropriate teaching methods and an uninteresting content of courses (curriculum). Teachers' pedagogical competence is regarded as an important parameter of a positive or negative students' attitude to SE courses in Junior and Senior High School. Lack of teachers' pedagogical training becomes obvious in the learning process through situations of terrorism and blackmail instead of praise and positive incentives. Teachers are presented not to have been taught about the skills needed to make their students capable of searching, thinking and reaching their own solution to a problem, thus to developing critical thinking. A need for teachers' professional development will be satisfied by further education and training through seminars. An able teacher is a teacher who knows which teaching practices and strategies to utilize to make a course attractive, strengthens "weak" students' efforts, helps students conquer knowledge, takes the age of the target group into consideration, connects the lesson with students' everyday life, shows enthusiasm during the teaching process, treats students equally, collaboratively, with kindness, love and a pedagogical purpose.

A very fruitful approach can be a socio-cultural one and, especially, an approach inspired by the cultural historical activity theory in formal and informal settings (Plakitsi et al., 2013). A proper way of teaching SE involves experiential and group-cooperative learning, students' active participation, simple and comprehensible framing of 
concepts, use of examples concerning daily life, conducting experiments (including students' participation) and contact with Nature. Equal discussion is a form of active participatory process. A course is based on examples of everyday life and builds on a child's experience, deals with issues related to the Environment a student lives in, sustains steady interest as relevant, useful, usable knowledge is offered. Experiential activities are combined with visits to museums and anthropogenic, natural environments that exploit students' senses. The possibilities of technology as well as screening documentaries and films enhance successful teaching. Synergism of activities is recommended because it aims at the cultivation of emotional intelligence and critical thinking. Above teaching methods enhance students' self-esteem and love for the course. Consequently, concepts which used to be incomprehensible and uninteresting through common teaching approaches can now be understood as well as the learning environment can now be pleasant. The degree of how much students' interests get satisfied by applied teaching practices in SE is very low, while the degree of how much school projects give students a hard time is too high. The infrastructure of a school and the opportunities for students to use existing equipment is extremely low. The objectives of the course are unclear and the attempt has not been worthwhile. A favorable treatment of students of the positive direction and teachers' indifference to the rest of the students lead to students' detachment and denial.

Students' answers to what they regard as the most important thing they have learned or remembered from SE courses vary. Seventy six of them expressed refusal, hatred and they think that SE courses offered them nothing in their adult lives questioning, as a result, their educational significance. They focused on the difficulty in understanding a formidable teaching and on the torture of monitoring and being assessed. An example of failure to connect SE with everyday life interprets students' failure to connect natural phenomena with mathematical formulas facing SE as a practice tool of Mathematics. Pleasant memories included experiments, teamwork that enhances learning, communication, childrens' positive attitude as well as visits outside the school.

In their opinion, SE courses cover a wide range of topics of interest, such as the study of natural and human environment. SE involves a variety of issues related to the Environment (ecological, biological, energy, natural resources, etc.). SE courses seem to have had a positive effect on the acquisition of knowledge. The study of natural environment includes understanding the function of natural laws, discovering natural environment, being environmentally aware. Students perceive education for the Environment as the triptych awareness-knowledge-sensitization goes and do not change their attitudes. Another important memory -knowledge from teaching SE courses- is the understanding of the natural forces that govern and form life on planet Earth. Natural laws, phenomena and their rationale, concepts, such as climate and weather, reflection and refraction of light, the rainbow, the motion of the earth around itself and the sun, the motion of planets are subjects learned in school and still remembered because they are interesting and connected with everyday life. A connection of SE courses with everyday life is considered to be an important part of their educational significance. Students explain everyday phenomena rationally and reconstruct their alternative ideas. Of course, participants perceive a student as a "little scientist", who studies, analyzes, comes to conclusions through the collected data. Students refer to SE as "logic" which is supposed to characterize the following process. The history of Science is a joyful remembrance which is seen as the most important thing they have earned after years of learning in Secondary Education. A student in everyday life needs experiments to interpret reality. Knowledge is not conquered through a single source which offers unilateral perspective of issues. Information should be analyzed and related to everyday life so as to be perceived and understood as new knowledge. Knowledge, of course, should not be described as a human construction but as a process of reality interpretation through analysis. There are views that describe knowledge provided by SE as a perpetual process of its own questioning rather than a rampant acceptance and submission to the absolute truth of the one and only knowledge.

\section{Discussion}

Analysis revealed important aspects of students' views (feelings, attitudes, interests) about Science and SE courses in Junior and Senior High School as well as the factors that influenced them. However, questions have emerged and seek answers. The research study showed that despite all the changes made to the curriculum of SE courses, the situation has not improved. A very large number of students seem to be alienated from Science, even though the latter has a dominant role in forming modern life in a personal and social level. Why cannot the curriculum lead to the overthrow of the existing, regressive situation and which forces act as a brake?

If we consider that curriculum is difficult to change the perceptions of Science in the near future, a change in the way of teaching, activities, learning motives would improve the situation. Good teaching enhances interest and stimulates students' desire to participate in the learning process, according to Osborne, Simon, and Collins (2003). Why, while 
the proper way of teaching SE courses is clearly described, shall it not be applied in practice? Research questions could be related to the study of the factors that would improve Science teachers' professional development by enhancing the nature and style of teaching as well as teaching practices.

The reasons why students deal with SE courses are their interest in participating in the course, the importance of the course and its usefulness so that they achieve a future goal. The inquiry of the factors, that shape students' perceptions of how significant knowledge provided by SE courses, public general education and the role of Science as part of public education is, would contribute to the creation of literate citizens and more specifically scientifically literate citizens. Finally, the perceptions and ideas that students-future teachers have about Epistemology of SE and the way of teaching SE is a matter of future inquiry.

\section{References}

Breakwell, G. M., \& Beardsell, S. (1992). Gender, parental and peer influences upon science attitudes and activities. Public Understanding of Science, 1(2), 183-197. http://dx.doi.org/10.1088/0963-6625/1/2/003

Britner, S. L. (2008). Motivation in high school science students: A comparison of gender differences in life, physical, and earth science classes. Journal of Research in Science Teaching, 45, 955-970. http://dx.doi.org/10.1002/tea.20249

Britner, S. L., \& Pajares, F. (2006). Sources of science self-efficacy beliefs of middle school students. Journal of Research in Science Teaching, 43, 485-499. http://dx.doi.org/10.1002/tea.20131

Christidou, V. (2011). Interest, attitudes and images related to science: Combining students' voices with the voices of school Science, teachers, and popular science. International Journal of Environmental, 6(2), 141-159.

Eisner, E. W. (1991). The enlightened eye: Qualitative inquiry and the enhancement of educational practice. New York, NY: Macmillan Publishing Company.

Finson, K. D. (2002). Drawing a scientist: What we do and do not know after fifty years of drawings. School Science and Mathematics, 102, 335-345. http://dx.doi.org/10.1111/j.1949-8594.2002.tb18217.x

Framework Programme 6. The 6th Framework Programme (FP) for Research and Technological Development. $\begin{array}{lllll}\text { Retrieved } & 2014 & \text { May } & 22 & \text { from }\end{array}$ http://europa.eu/legislation_summaries/research_innovation/general_framework/i23012_en.htm

Framework Programme 7. The 7th Framework Programme funded European Research and Technological Development from 2007 until 2013. Retrieved 2014 May 22 from http://cordis.europa.eu/fp7/home_en.html

Gough, A. (2002). Mutualism: A different agenda for environmental and science education. International Journal of Science Education, 24, 1201-1215. http://dx.doi.org/10.1080/09500690210136611

Häussler, P., \& Hoffmann, L. (2000). A curricular frame for Physics education: Development, comparison with students' interests, and impact on students' achievement and self-concept. Science Education, 84, 689-705. http://dx.doi.org/10.1002/1098-237X(200011)84:6<689::AID-SCE1>3.0.CO;2-L

Havard, N. (1996). Student attitudes to studying A-level sciences. Public Understanding of Science, 5(4), 321-330. http://dx.doi.org/10.1088/0963-6625/5/4/002

Hill, D., \& Wheeler, A. (1991). Towards a clearer understanding of students' ideas about science and technology: An exploratory study. Research in Science and Technological Education, 9, 125-137. http://dx.doi.org/10.1080/0263514910090202

Horizon 2015-2020. Retrieved 2014 May 22 from http://ec.europa.eu/programmes/horizon2020/

Kahle, J., \& Lakes, M. (1983). The myth of equality in science classrooms. Journal of Research in Science Teaching, 20, 131-140. http://dx.doi.org/10.1002/tea.3660200205

Krapp, A., \& Prenzel, M. (2011). Research on Interest in Science: Theories, methods, and findings. International Journal of Science Education, 33(1), 27-50. http://dx.doi.org/10.1080/09500693.2010.518645

Miller, J. D., Pardo, R., \& Niwa, F. (1997). Public Perceptions of Science and Technology: A Comparative Study of the European Union, the United States, Japan, and Canada. Madrid: BBVA Foundation

Myers, R. E., \& Fouts, J. T. (1992). A cluster analysis of high school science classroom environments and attitude toward science. Journal of Research in Science Teaching, 29, 929-937. http://dx.doi.org/10.1002/tea.3660290904 
OECD. (2006). Assessing Scientific, Reading and Mathematical Literacy: A Framework for PISA 2006. Paris: OECD. http://dx.doi.org/10.1787/9789264026407-en

Oliver, J. S., \& Simpson R. D. (1988). Influences of attitude toward science, achievement motivation, and science self concept on achievement in science: a longitudinal study. Science Education, 72, $143-155$. http://dx.doi.org/10.1002/sce.3730720204

Ormerod, M. (1971). The 'social implications' factor in attitudes to science. British Journal of Educational Psychology, 41, 335-338. http://dx.doi.org/10.1111/j.2044-8279.1971.tb00683.x

Osborne, J. F., \& Collins, S. (2000). Pupils' and parents' views of the school science curriculum. London: King's College London.

Osborne, J., Simon, S., \& Collins, S. (2003). Attitudes towards science: a review of the literature and its implications. International Journal of Science Education, 25, 1049-1079. http://dx.doi.org/10.1080/0950069032000032199

Papantoniou, G., Moraitou, D., Kaldrimidou, M., Plakitsi, K., Filippidou, D., \& Katsadima, E. (2012). Affect and cognitive interference: An examination of their effect on self-regulated learning. Education Research International. http://dx.doi.org/10.1155/2012/579590

Plakitsi, K. (Ed.), (2013). Activity Theory in Formal and Informal Science Education. Series: Cultural perspectives in science education: Research dialogs. Series editor: Kenneth Tobin, City University of New York, USA, and Catherine Milne, New York University, p. 252. Rotterdam: Sense Publishers.

Rubin, E., Bar, V., \& Cohen, A. (2003). The images of Scientists and Science among Hebrew- and Arabic-speaking pre-service teachers in Israel. International Journal of Science Education, 25, 821-846. http://dx.doi.org/10.1080/09500690305028

Scherz, Z., \& Oren, M. (2006). How to change students' images of science and technology. Science Education, 90, 965- 985. http://dx.doi.org/10.1002/sce.20159

Sink, C. A., \& Spencer, L. R. (2005). My class inventory - Short Form as an accountability tool for elementary school counselor to measure classroom climate. Professional School Counseling, 9(1), 37-48. http://dx.doi.org/10.5330/prsc.9.1.y720844684111402

Sjøberg, S. (2000). Interesting all children in 'science for all'. In R. Millar, J. Leach \& J. F. Osborne (Eds.), Improving science education (pp. 165-186). Buckingham: Open University Press.

Weinburgh, M. H., \& Englehard, G. Jr. (1994). Gender, prior academic performance and beliefs as predictors of attitudes toward biology laboratory experiences. School Science and Mathematics, 94, 118-123. http://dx.doi.org/10.1111/j.1949-8594.1994.tb15635.x

Whitfield, R. C. (1980). Educational research \& science teaching. School Science Review, 60, 411-430.

Woolnough, B. (1994). Effective science teaching. Buckingham: Open University Press. 